\title{
Estimation of Cooling Load of a Residential House using TRNSYS
}

\author{
Kornu Mohan Laxmi ${ }^{1}$ and V.V.S. KesavaRao ${ }^{2}$ \\ ${ }^{1}$ Part time PhD scholar, Department of Mechanical Engineering, College of Engineering(A), Andhra \\ University, Visakhapatnam, India \\ ${ }^{2}$ Professor, Department of Mechanical Engineering, College of Engineering(A), Andhra University, \\ Visakhapatnam, India
}

\begin{abstract}
Development of a country will lead to increased utilization and demand for energy. In this research study, transient simulation technique is implemented and eventually, the cooling load of the house is determined. The study focused to provide cooling load characteristics for a residential house. The factors namely: size and shape, thermophysical properties, window systems, orientation, internal gains, ventilation and infiltration aspects that influence the cooling load are considered in the study. A dynamic simulation software-TRNSYS (Transient Systems Simulation Program) is used for the modelling and simulation of the energy flows of the house to determine the cooling thermal load. The study is useful in providing a better solution for a sustainable future by simulating with different design modifications of the house. This study may be extended to focus on the choice of constructional materials, so that good temperature and lower cooling load are attained. A case study of a residential building is situated in the coastal district of Andhra Pradesh, India and located at Latitude $\left(17.68^{\circ} \mathrm{N}\right)$ and longitude $\left(83.21^{\circ} \mathrm{E}\right)$ is considered to find cooling load through TRNSYS 16.
\end{abstract}

Keywords:

\section{INTRODUCTION}

In India, most areas experience hot summer seasons with high ambient temperatures. In cities during the summer, people spend more time indoors so buildings should be made comfortable for hot weather conditions. In cities, most residential buildings are with multiple storeys, with fired bricks walls and flat reinforced concrete (RC) slab roofs and most of the houses have 2-4 rooms. These RC roofs retain heat absorbed in the daytime and emit it during the night affecting comfort in buildings when all family members are in. This is worst for congested areas and houses with cooling systems (fans, coolers, and air conditioners) combined with poor ventilation, making sleeping difficult, affecting people's comfort and health. Rooms are uncomfortable during the peak summer season (also in winter) due to many hours of electricity cuts although cooling systems are in place. 
For the simulation of building cooling load in the climatic conditions of a city, a simple multi-zone building was selected as TRNSYS 'TYPE 56' required a minimum of two thermal zones. This model was based on a common, typical construction design and materials of multi-storey houses in the north coastal district of Andhra Pradesh.

\section{TRaNsientSYstem Simulation (TRNSYS)}

TRNSYS is a frequently implemented, thermal process-related dynamic simulation program. It was initially developed for solar energy-related applications, and can now be used for a wider variety of thermal processes. TRNSYS can be used for simulation of solar PV, solar heating and cooling and building energy. It has the capability to interconnect components of thermal systems in any desired manner and output is obtained by solving differential equations. Given OUTPUT from one component is used as an INPUT to other components. Each component of the software has a unique number (TYPE), and components from the standard library of TRNSYS were validated.

There are some compatible components developed by Thermal Energy System Specialists (TESS) which are useful for modelling and analysis of buildings and other energy systems. TRNSYS is provided with simulation studio which is a graphic user interface environment. The simulation studio consists of customized components which can be dragged and dropped to configure a real system for simulation. The standard library includes approximately 150 models ranging from photovoltaic panels, multi-zone buildings, solar collectors, storage tanks, weather data processors and HVAC equipment. The components of the system need to be specified through a set of parameters, inputs and outputs. The output parameters may be used as input parameters for others in the system. The output can be stored in a file and inputs may be fed through a file. There are also components like printers and plotters to visualize the simulation process.

TRNSYS includes Trnsys3d, a plug-in for Sketch-Up that allows multi-zone buildings to be drawn and imports the geometry directly from the Sketch Up interfaces into TRNSYS. Building a model of TRNSYS makes use of TRNBuild to create and edit the information related to non-geometry in nature. TRNBuild has the flexibility to change the regime data (profiles of ventilation, infiltration, internal gains, cooling/heating, comfort and humidity) of a thermal zone of a building. The user can edit the wall and the material properties of layers of the wall.

The TRNSYS simulation software contains weather data component of different types. Weather conditions and loads are factors that affect cooling system performance. Loads are dependent on weather for cooling and heating in building structures and also other factors which are not related to weather. The weather component contains meteorological data like ambient temperature, solar radiation and wind speed, wind direction and relative humidity. 
In the weather data reading component, TMY is a one type data set contains hourly values of meteorological elements and solar radiation for a period of one year. It consists of typical months of real weather data selected from different years and combined to form a data set of a year of typical weather. It provides hourly data for meteorological elements that contribute to performance comparisons for different types for single or multiple locations. It is not a good indicator for predicting the system parameters for the next one or five years as selected data is data for a typical month.

\section{Literature Review}

Energy performance of buildings is a critical issue to academics and researchers at present in order to reduce environmental pollution and increase energy efficiency.

Franck Lucas et al. (1998) developed multi-zone housing models through TRNSYS and CODYRUN in a wet tropical climate. The authors analyzed the impact of meteorological parameters and parameters of building envelop. The results obtained through simulation by both the models are compatible and comparable with the results of the experiment.

Nilufer Egrican and AlpayAkguc (2011) modelled a building integrated photovoltaic system and simulated building energy using TRNSYS. From the study, the authors concluded that heating demand increases and cooling demand decreases during summer and winter seasons respectively due to integrated photovoltaic system.

Petrus and Gilani (2011) studied the cooling load characteristics of an academic building using TRNSYS. In the study, it was observed that heat gain from the building envelop is the major contribution towards cooling load.

Hani H. Sait (2013), used hand calculation and HAP 4.2 program and predicted thermal load for a building. The author concluded that there is a little difference in thermal loads predicted by the methods.

Luca Evangelisti et al. (2014) predicted monthly demand for energy in respect of house, flat and old building through TRNSYS and MC11300 and made a comparison. The authors concluded that MC11300 predicted higher values in case of heating demand. In the case of cooling demand prediction, TRNSYS shows higher values.

Takahashi et al. (2014) determined cooling/heating loads to implement the life cycle energy management using simulation tools (TRNSYS and HASP/TES). The authors made the study for a building in TOKYO and concluded that their calculation results had a similar trend.

Naranjo-Mendoza et al. (2015) developed TRNSYS modelling for Solar cooling System (Vapour Absorption) and simulated to a case study of an office building of Guayaquil, Ecuador and predicted the thermal 
demand. The authors concluded that there is $60 \%$ of solar fraction and identified optimal values of collector slope, surface slope and collector mass flow rate.

Matteo Dongellini et al. (2016) developed a multi-zone building model for a case study of an academic building in ITALY and simulated through TRNSYS17. In the study, the authors predicted the energy requirement for heating for the comfort of students in a cool environment.

Gupta et al. (2017), considered five zones building of an office and solar cooling system performance is analyzed through TRNSYS. The authors considered four cities to represent four climatic zones of India. The authors identified the energy savings ranging from $44 \%$ to $62 \%$ in the four climate zones.

Farrajet al. (2017) considered domestic houses in Kuwait and analyzed the energy performance of the houses through TRNSYS-IISIBAT simulation environment. The authors conducted parametric studies to know the sensitivity of building envelope, window parameters, ventilation profiles and infiltration profiles. The authors concluded that the classical wall (Cement Block) is superior to AAC wall (Autoclaved Aerated Concrete) in energy efficiency perspective.

Cristina Baglivo et al. (2017), developed a building prototype model using TRNSYS 17 and analyzed thermal behaviour and the impact of the components (slab-on-ground floor, walls, windows, shading roof and internal heat loads) on the thermal load of the building. The authors arrived at the optimum values of attenuation factor, internal area, heat capacity and time shift for optimum external thermal loads.

YamiléDíaz-Torres et al. (2017) developed the operating strategy for water-cooled chiller system of a hotel through simulation using TRNSYS software. The authors analyzed HVAC system different impact parameters such as weather conditions, construction parameters and occupancy.

Khoa Xuan Le (2018) modelled a heat pump (Retrofit high-temperature air sourced) and analyzed the performance through TRNSYS. Also, the results obtained through modelling are validated by results obtained through field trials.

Wenting Ma et al. (2019) developed Water Source Heat Pump (WSHP) and Ground Source Heat Pump (GSHP) systems using TRNSYS for an office building situated in Suzhou to analyze the performance on long term perspective.

Carolina Aparicio-Fernández et al. (2019) predicted energy demand of a residential building and evaluated the energy performance of the building through TRNSYS and TRNFlow. The authors studied the impact of infiltration profile and natural ventilation profiles and made a conclusion that ventilation rate in respect of natural ventilation can improve energy performance. 


\section{Literature gap:}

The energy performance of buildings is of has been becoming important in the world's energy policy. Though some computational soft-wares are available, model development and dynamic simulation and modelling of the energy performance of buildings are limited. The present study developed a building model and presented a dynamic simulation to evaluate the cooling load of a residential house through TRNSYS. The study made in the paper is useful to make sensitivity analysis to analyze the impact of the building envelope parameters, regime data profiles of a building dynamically. Designing new models with challenging variants of building parameters is possible through TRNSYS. TRNSYS-based modelling and simulation enable users to analyze different climatic conditions, building envelops orientation of building to arrive cooling load with hardly any knowledge in simulation and modelling.

\section{METHODOLOGY}

\section{TRNSYS Simulation Studio}

The 3D building model created in Sketchup was imported to the TRNSYS simulation studio. The simulation studio is the main simulation engine of TRNSYS with graphical plotting and output with spreadsheet facilities. TRNSYS components are called 'Types' and each Type is assigned a number; for the building model, 'Type56' was used. The systematic import of 3D building models to simulation studio is necessary to simulate the building model for further simulation of solar cooling of the building.

The two-story building considered in this study is situated in the coastal district of Andhra Pradesh, India and located at Latitude $\left(17.68^{\circ} \mathrm{N}\right)$ and longitude $\left(83.21^{\circ} \mathrm{E}\right)$ The City lies on $28 \mathrm{~m}$ above sea level has a tropical climate. The following steps are necessary to create a Type56-building model.

Step-1: Import of the TRNSYS3D model into the simulation studio.

In the TRNSYS studio, the multi-zone building project is selected in the new project menu.

Step-2: Import of the TRNSYS3Dmodel into the simulation studio.

In this step, the building rotation was set to a default value of zero and the location was set to the city under consideration, by selecting TMY2 weather data for the city available in TRNSYS weather data.

During the import, TRNSYS calculates the volume of zones, the number of surfaces, view factor to sky calculation, sorting of zones/air nodes and surfaces. It generates a *.BUI file and opens it in TRNBuild and *_b17_IDF (this file can be used to go back from TRNBuild to Trnsys3d GUI) with the same order of zones and surface numbers. All Building-related materials, geometry and thermal properties are viewed and modified in the TRNSYS plug-in called TRNBuild. TRNBuild opens independently or by right-clicking on building Type 56 using 'edit building'. 
Step-3: Setting the Building's initial parameters.

In TRNBuild, building materials, thermal calculation parameters and the model construction, with details of walls and windows for zones, are assigned according to selected standards. In TRNBuild American/ASHRAE, French, German, Japanese, Spanish and TESS standard libraries are available and American/ASHRAE is selected as a default standard. The initial values for building materials, thermal comfort and other parameters were used from TRNBuild pre-defined 'default' values selected within the American/ASHRAE standard. The details of some default and initial parameters used in the simulation are described here.

Settings Menu: Settings menu is used to set up some general settings for the simulation. These basics settings include data files location, selected standard libraries, import and export model applications, TRNSYS input data files, and some other parameters required for the TRNSYS program applications for simulation

Project settings: Project settings include building orientations and miscellaneous settings. The orientations menu shows the orientation of building surfaces. Each orientation is described by direction (N, S, E, W or $\mathrm{H}$ ), Azimuth angle of orientation (0-South, 90-West, 180-North and 270-South) and slope of orientation (0Horizontal, 90-Vertical and 180- Facing down). When the initial building rotation is set (shown in Figure 6-7) the orientations are assigned to the model surfaces by the TRSNYS program.

Miscellaneous settings: Miscellaneous settings include properties, inputs and outputs. The properties are material thermal properties; some are general properties and others are parameters for internal calculation of heat transfer coefficients. Heat transfer coefficients depend heavily on the temperature difference between surface and fluid and direction of heat flow. TRNBuild automatically selects 'default' values for properties during the model import

Step-4: Setting up Zones' thermal and material properties.

The zones window contains all information for thermal zones in the building model. A thermal zone may have more than one air node. The air nodes can move within a zone for multi air nodes zones. The Zones window describes an air node's regime data, walls, windows and optional building equipment and operation specifications including infiltration, ventilation, cooling, heating, gains and comfort and geometry modes.

Regime Data: Regime data includes a volume of air node, total thermal capacitance $\mathrm{kJ} / \mathrm{K}$ (standard is 1.2 $\times$ zone volume), initial temperature, initial relative humidity and humidity model for air nodes. The zone initial temperature and initial relative humidity used were $20^{\circ} \mathrm{C}$ and $50 \%$ respectively. In the case of the building model, TRNBuild takes a zero value for capacitance as its default. For initial simulation, all default parameters are used

Walls: For the building model, TRNBuild calculates parameters and assigns materials including wall type, wall area, wall category (external, internal, adjacent and boundary) surface number and wall gain. TRNBuild 
contains a library according to the selected standard for walls and a new wall type can be defined. It also calculates total wall thickness and standard $\mathrm{u}$-value according to the wall material.

Similarly, for the wall layer, a standard library is available and the user can define a new layer. New layer definition has four category options that are: massive (normal construction), massless (to neglect thermal mass), active (concrete core cooling and heating) and chilled ceiling (chilled ceiling panel).

In addition to wall constructions, the coefficient of solar absorptance is also required as shown in Figure 613. It depends upon the properties of the wall finishes and the standard value for each surface is available in the library. TRNBuild uses default values automatically and changes are possible if required. Finally, the convective heat transfer coefficient of the wall required and standard values are: inside $-11 \mathrm{~kJ} / \mathrm{h}-\mathrm{m}^{2} \mathrm{~K}$ and outside $-64 \mathrm{~kJ} / \mathrm{h}$ $\mathrm{m}^{2} \mathrm{~K}$.

The detailed description of other wall types and materials is as follows. By default TRNBuild assigned standard materials to the adjacent wall (the partition between zones) front/inside with three materials layers (plasterboard, fibreglass and plasterboard) with a total thickness of $0.090 \mathrm{~m}$ and $\mathrm{u}$-value of $0.508 \mathrm{~W} / \mathrm{m} 2 \mathrm{~K}$. The external wall was assigned with three material layers (plasterboard, ASHRAE fibreglass and ASHRAE wooden sidings) with a total thickness of $0.087 \mathrm{~m}$ and a $\mathrm{u}$-value of $0.510 \mathrm{~W} / \mathrm{m} 2 \mathrm{~K}$. The solar absorptance of all walls is 0.6 for both sides. The longwave emission coefficient of all walls is 0.90 for both sides.

Windows: In TRNBuild, windows can be defined for external and adjacent walls. Windows can be added, edited or deleted depending upon the geometry mode settings. The specifications for windows geometry and materials include windows type, area, category, surface number, gain, orientation and shading device. The TRNBuild contain standard and the default setting for windows.

Different materials, glazing, frame and optional properties of shading devices including convective heat transfer coefficients may be assigned for a window. TRNBuild contains a standard library for windows according to the available standards. In the library, each type is assigned with an ID number, u-value, g-value, convective heat transfer coefficient, frame properties and optional properties of shading devices.

Infiltration: Airflow into the zone from outside is specified by infiltration. In TRNBuild, infiltration is optional and it can be a constant value, an input or scheduled value. The infiltration is defined in terms of a number of air changes per hour $(\mathrm{ACH})$. By default, infiltration is off for the initial simulation parameter.

Ventilation: Airflow from external heating or cooling equipment into the zone is specified by ventilation. In TRNBuild, ventilation is optional and it can be defined by airflow (air change rate or mass flow rate), the temperature of airflow (outside or other) and humidity of airflow (relative or absolute humidity and outside or 
other). By default, ventilation is off and the user can create different types of ventilation. For initial simulation, default parameters are used.

Heating: Heating requirements and heating control in any zone are defined by heating type. Using heating in a zone is optional and by default, it is off. Heating control is defined by set temperature, heating power (unlimited or limited) and humidification (off or on with relative or absolute humidity). For initial simulation, default parameters are used.

Cooling: Cooling requirements and cooling control in any zone is defined by cooling type. Use of cooling in the zone is optional and, by default, it is off. Cooling control is defined by set temperature, cooling power (unlimited or limited) and humidification (off or on with relative or absolute humidity). For initial simulation, default parameters are used.

Gains: Internal gains including persons, electrical devices and lighting are defined by gains. Gains are optional and by default, they are off. A person's activity gains are defined according to the ISO 7730 standard. Use of computer and artificial lighting is optional. Gains are from a standard library and the user defines other gains which are available according to selected standards. For initial simulation, default parameters are used (no gain at all).

Comfort: Thermal comfort calculations are based on the ISO 7730 standard. Specification of comfort is optional and by default, the comfort setting is off. The user can define the comfort type based on clothing factor, metabolic rate, external work and relative air velocity. The internal calculation based on comfort is calculated by a simple model (based on area-weighted mean surface temperature) or a detailed model (based on the view factor of reference point). For initial simulation, default parameters are used, which is that no comfort standard is used.

Schedule: TRNBuild offers a scheduling system for infiltration, cooling, heating, ventilation, gains and comfort. The schedule types are, day-night, and light, set off, use, weekend, workday and work light. Frequency is daily or weekly with any start-stop times during the 24-hour duration. For initial simulation, no schedule is used.

Geometry and Radiation Modes: Radiation modes of thermal zones are for direct and diffuse shortwave and longwave radiation distribution within zones. The available options are beam radiation and diffuse radiation distribution with standard and detailed models, and longwave radiation exchange with a zone offering standard, simple and detailed models.

Step-5: Building model initial simulation.

After the model import in TRNSYS with all the default settings and parameters selected as initial parameters for the building model with Lahore TMY2 data, a simulation was executed and initial results were obtained. The 
TRNBuild default building model outputs were zone air temperatures and sensible heat required for the zone (positive for cooling and negative for heating). For initial results, only zone temperatures were plotted to study the room's temperatures with (American/ASHRAE) TRNBuild pre-selected default parameters.

Step-6: Internal gains and infiltration addition.

The first change made in the building parameters was the addition of internal gains, infiltration and ventilation to room as the TRNSYS default settings do not use any gain or infiltration. This addition made the simulation results more realistic and estimated the maximum room temperature and cooling load with gains and losses. Internal gain used the default ISO 7730 standard with the presence of one person with light activity from $4 \mathrm{pm}$ to $9 \mathrm{am}$ and a $100 \mathrm{~W} / \mathrm{m} 2$ incandescent lamp and one TV/computer of power $140 \mathrm{~W}$ as the internal gains. Infiltration was set according to the LEED standard as $0.2(\mathrm{ACH})$ and ventilation as $2.0(\mathrm{ACH})$ with ambient temperature and humidity. The simulation results after addition of gains and losses need to be analyzed.

Step-7: Analysis of internal gains and infiltration addition.

In general, there is an increase in room air temperature due to an increase in internal heat gain and infiltration of ambient air. The peak temperature during the summer is more than $50^{\circ} \mathrm{C}$. Ventilation is heat input to the room in the middle of the day when the ambient temperature is high and heat removal is at night when the ambient temperature is lower, which lowers the room temperature.

Step-8: Building model modification.

From the initial results, it is necessary to analyze the need to modify building construction materials and operating parameters to improve building comfort levels and minimize the cooling load before designing a cooling system to maintain the standard comfort conditions inside the room.

\section{RESULTS AND DISCUSSION}

\section{Building Model Simulation}

The dimensions of the building are $14.88 \mathrm{~m} \times 8.76 \mathrm{~m} \times 3.4 \mathrm{~m}$. The exterior walls of building consist of $230 \mathrm{~mm}$ common bricks + air space $+230 \mathrm{~mm}$ common bricks with $13 \mathrm{~mm}$ cement mortar and $26 \mathrm{~mm}$ (13 mm both side) sand cement plaster. The interior walls of the building consist of $230 \mathrm{~mm}$ common bricks with 26 (13 mm both side) inch sand cement plaster. The roofs consist of $152 \mathrm{~mm}$ concrete poured in a metal sheet with $13 \mathrm{~mm}$ plaster. The windows consist of single glass materials of $8.5 \mathrm{~mm}$ thick with a frame panel. The building plan is presented below. 


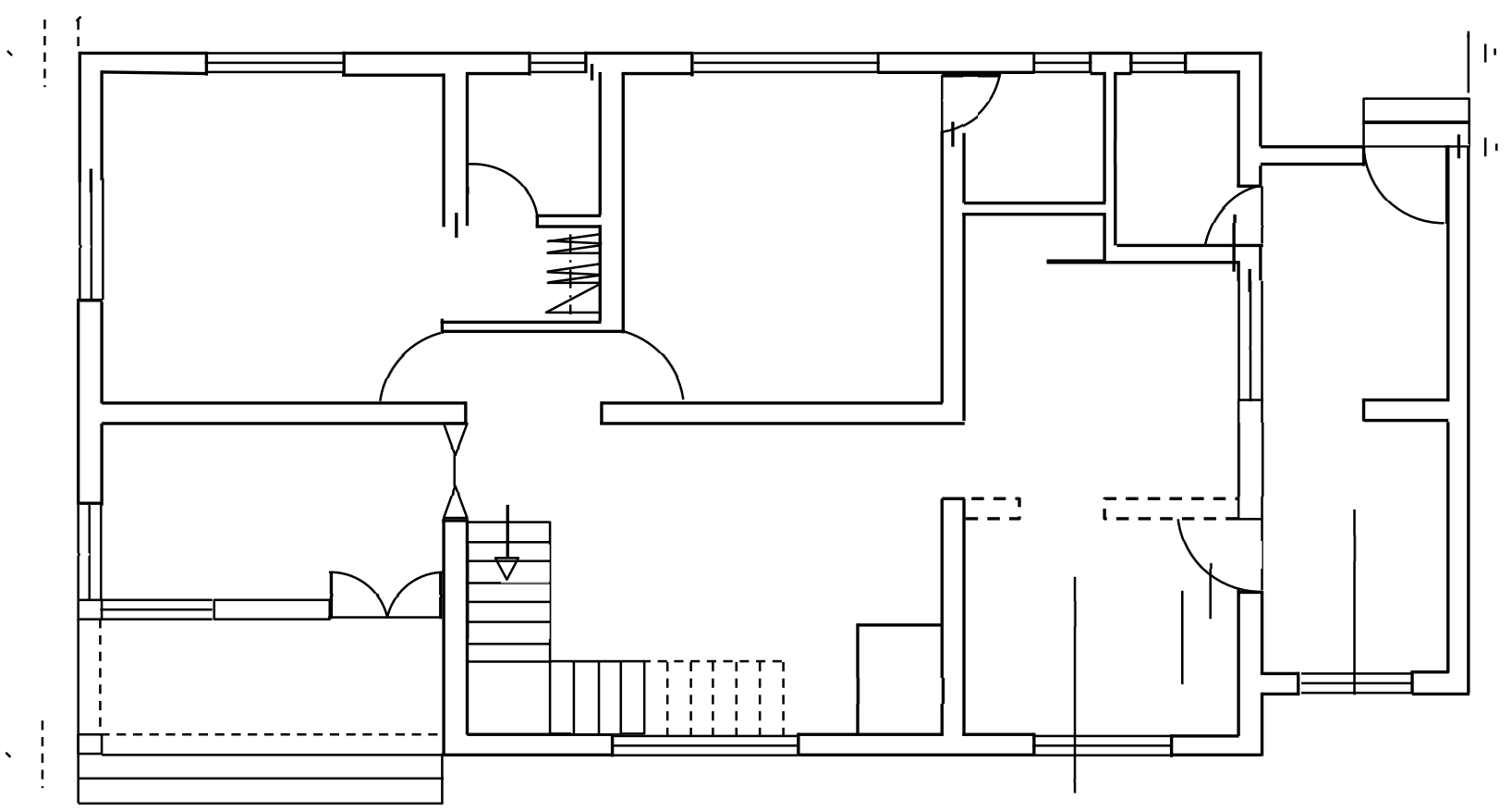

Fig. 1: Building plan

Table-1: Areas of rooms

\begin{tabular}{|c|c|c|c|c|c|}
\hline S.No. & Room & Width & Length & Area & Ceiling Height(m) \\
\hline 1 & Master Bed Room & 3.66 & 4.14 & 15.15 & 3.4 \\
\hline 2 & Bed Room & 3.42 & 4.14 & 14.16 & 3.4 \\
\hline 3 & Office & 3.66 & 2.22 & 8.13 & 3.4 \\
\hline 4 & Living & 5.1 & 3.9 & 19.89 & 3.4 \\
\hline 5 & Dining & 2.94 & 2.94 & 8.64 & 3.4 \\
\hline 6 & Kitchen & 2.94 & 2.7 & 7.94 & 3.4 \\
\hline 7 & Work Area & 1.98 & 6.12 & 12.12 & 3.4 \\
\hline 8 & Toilet1 & 1.44 & 1.8 & 2.59 & 3.4 \\
\hline 9 & Toilet2 & 1.5 & 1.63 & 2.44 & 3.4 \\
\hline 10 & Toilet3 & 1.32 & 2.16 & 2.85 & 3.4 \\
\hline
\end{tabular}


Table-2: Areas of windows

\begin{tabular}{clccc}
\hline & & Windows & & \\
\hline S.No. & Room & width & Height & Area \\
\hline 1 & Master Bed Room (S) & 1.5 & 1.35 & 2.025 \\
2 & Master Bed Room (W) & 1.5 & 1.35 & 2.025 \\
3 & Bed Room(W) & 2 & 1.35 & 2.70 \\
4 & Office (S) & 1.2 & 1.35 & 1.62 \\
5 & Office (E) & 1.2 & 1.35 & 1.62 \\
6 & Living(E) & 2 & 1.95 & 3.90 \\
7 & Dining & 1.2 & 1.35 & 2.025 \\
8 & Kitchen(E) & 1.5 & 1.11 & 1.65 \\
9 & Work Area(E) & 1.2 & 1.0 & 1.20 \\
10 & Toilet1-Ventilator & 0.6 & 0.6 & 0.36 \\
11 & Toilet2-Ventilator & 0.6 & 0.6 & 0.36 \\
12 & Toilet3-Ventilator & 0.6 & 0.6 & 0.36 \\
\hline
\end{tabular}

Table-3: Areas of doors

\begin{tabular}{clccc}
\hline S.No. & Door & Width & Height & Area \\
\hline 1 & Master Bed Room & 0.9 & 2.1 & 1.89 \\
2 & Bed Room & 0.9 & 2.1 & 1.89 \\
3 & Office & 1.2 & 2.1 & 1.89 \\
4 & Living & 0.75 & 2.1 & 2.52 \\
5 & Dining & - & - & - \\
6 & Kitchen & 0.9 & 2.1 & 1.89 \\
7 & Work Area & 0.9 & 2.1 & 1.89 \\
8 & Toilet1 & 0.75 & 2.1 & 1.575 \\
9 & Toilet2 & 0.75 & 2.1 & 1.575 \\
10 & Toilet3 & 0.75 & 2.1 & 1.575 \\
\hline
\end{tabular}




\subsubsection{Simulation using TRNSYS}

Select the new project from the menu: The window looks as below:

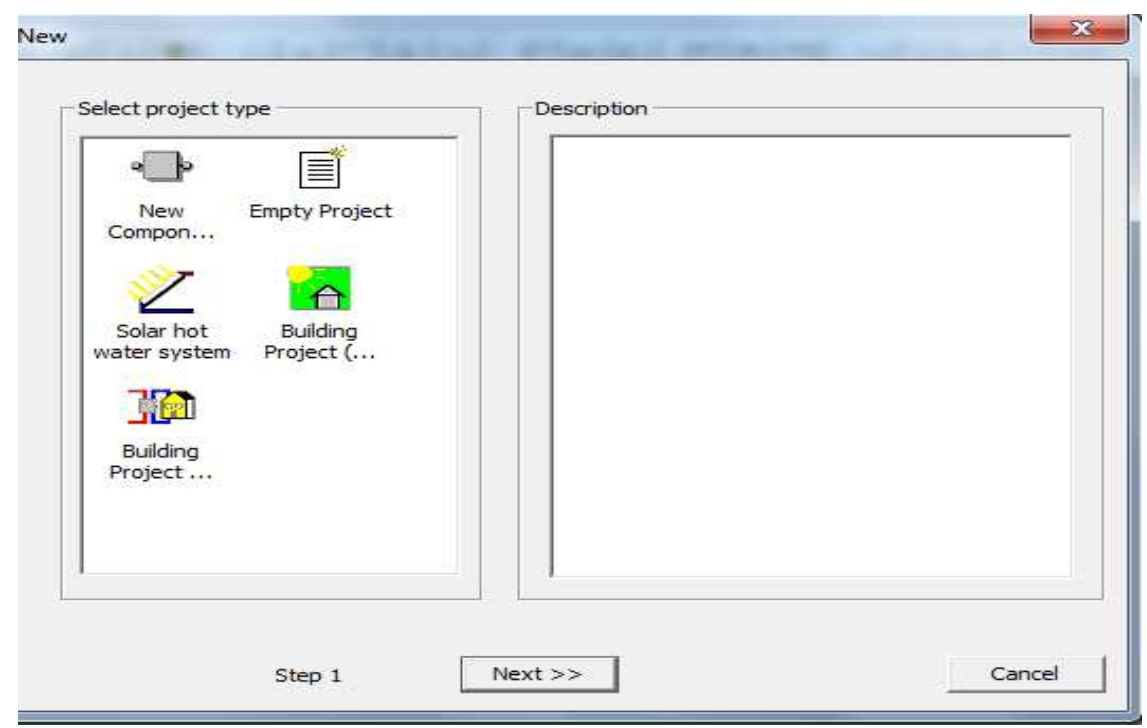

Fig. 2: New project from the menu

From the window select building project (Multi-Zone). Add the number of zones of the building under study. Define zone Dimensions. Select the TMY2 weather data for the city under consideration available in TRNSYS weather data. After the import of Trnsys3d model, the final window in the simulation studio is shown below.

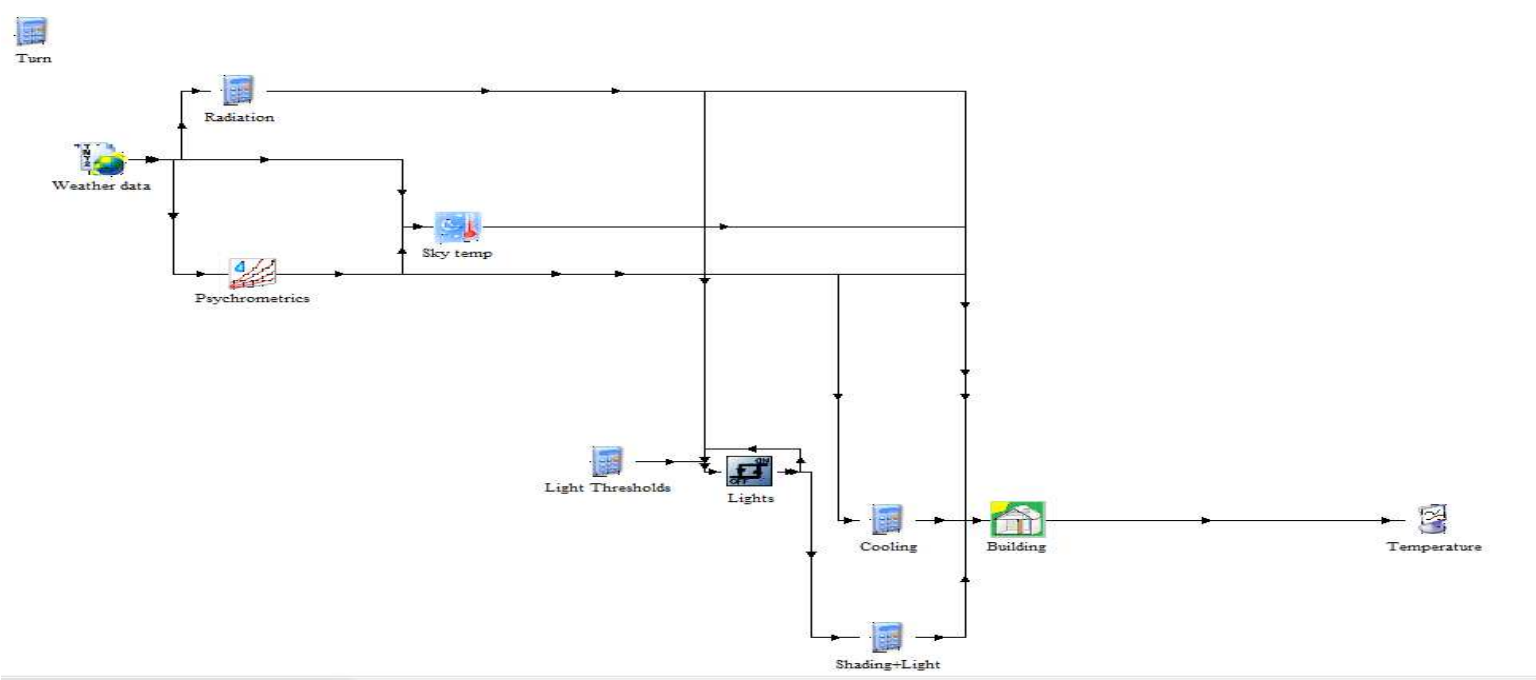

Fig. 3: Final window in the simulation studio

Initial simulation results: The building model with the city under case study TMY2 data, a simulation was executed and initial results were obtained. 
The building considered in this study is situated in the coastal district of Andhra Pradesh, India and located at Latitude $\left(17.68^{\circ} \mathrm{N}\right)$ and longitude $\left(83.21^{\circ} \mathrm{E}\right)$ The City lies on $28 \mathrm{~m}$ above sea level has a tropical climate. The diffuse and normal radiation is presented in the following chart.

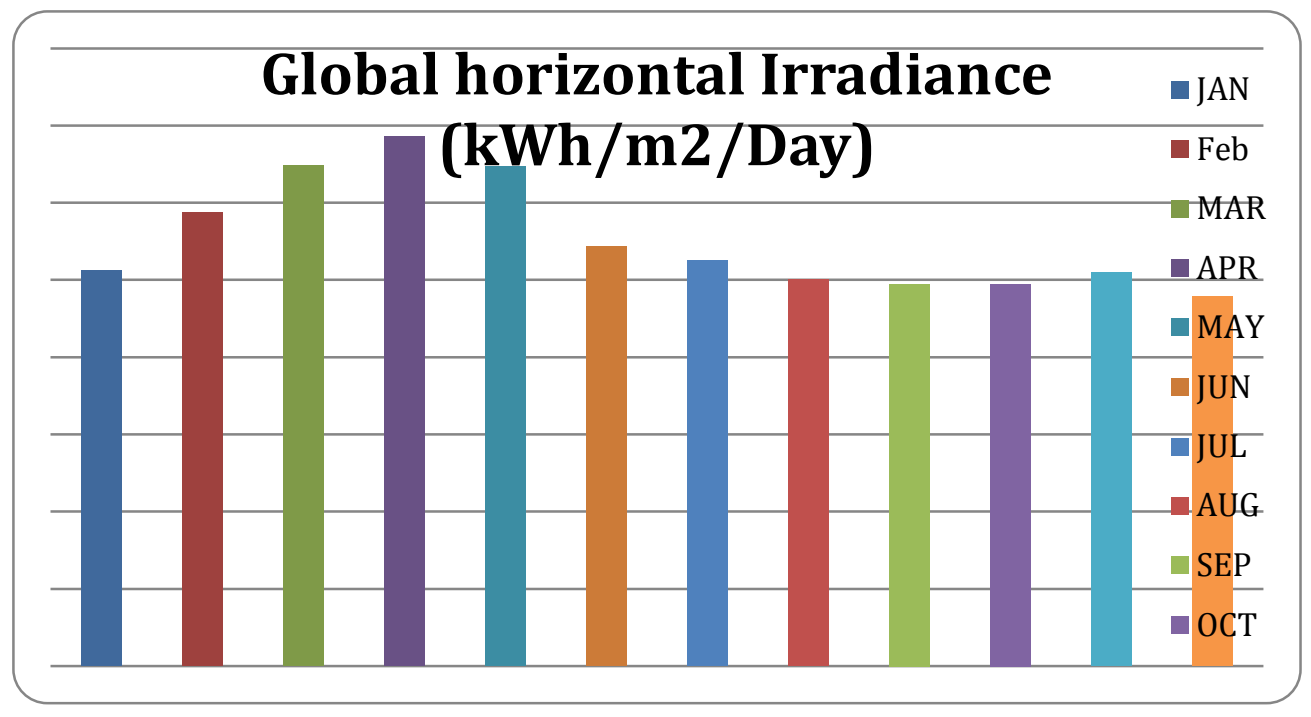

Fig. 4: Diffuse and normal radiation

From the chart, it is observed that the average highest global Horizontal Irradiance is observed in the month of April followed by May of 6.86 and 6.47 respectively. The ambient temperature distribution is presented in Fig. 5.

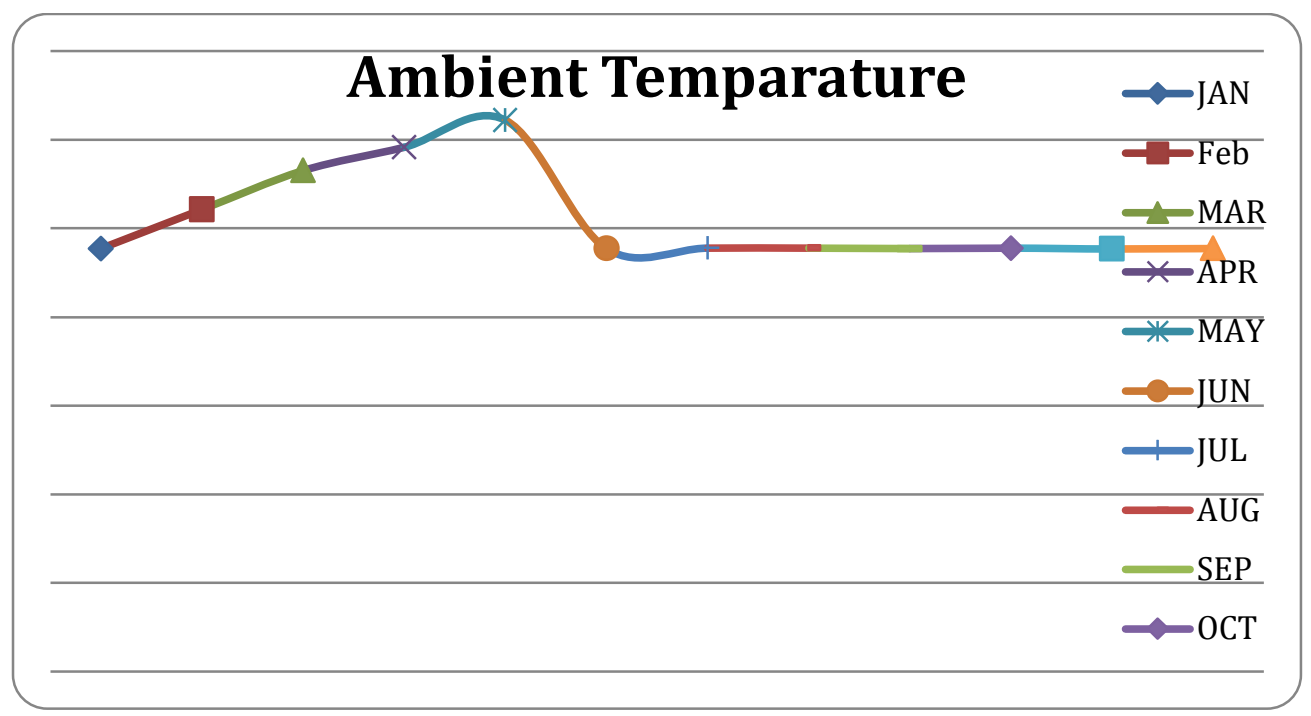

Fig. 5: Ambient temperature distribution 
From the figure, it is observed that the highest temperature of $31.1^{\circ} \mathrm{C}$ is observed in the month of May followed by $29.58^{\circ} \mathrm{C}$ in the month of April. Hence to determine cooling load the month of May is considered.

The simulation time-step was one hour and the total duration was 744 hours for the month of May (744 hours). Different room's temperatures were plotted to observe the inside air temperature. The day-wise temperature plot of Dining, Kitchen, Storage, Master Bed Room, Bed Room, Office Room and Living Room are shown in Fig.6.

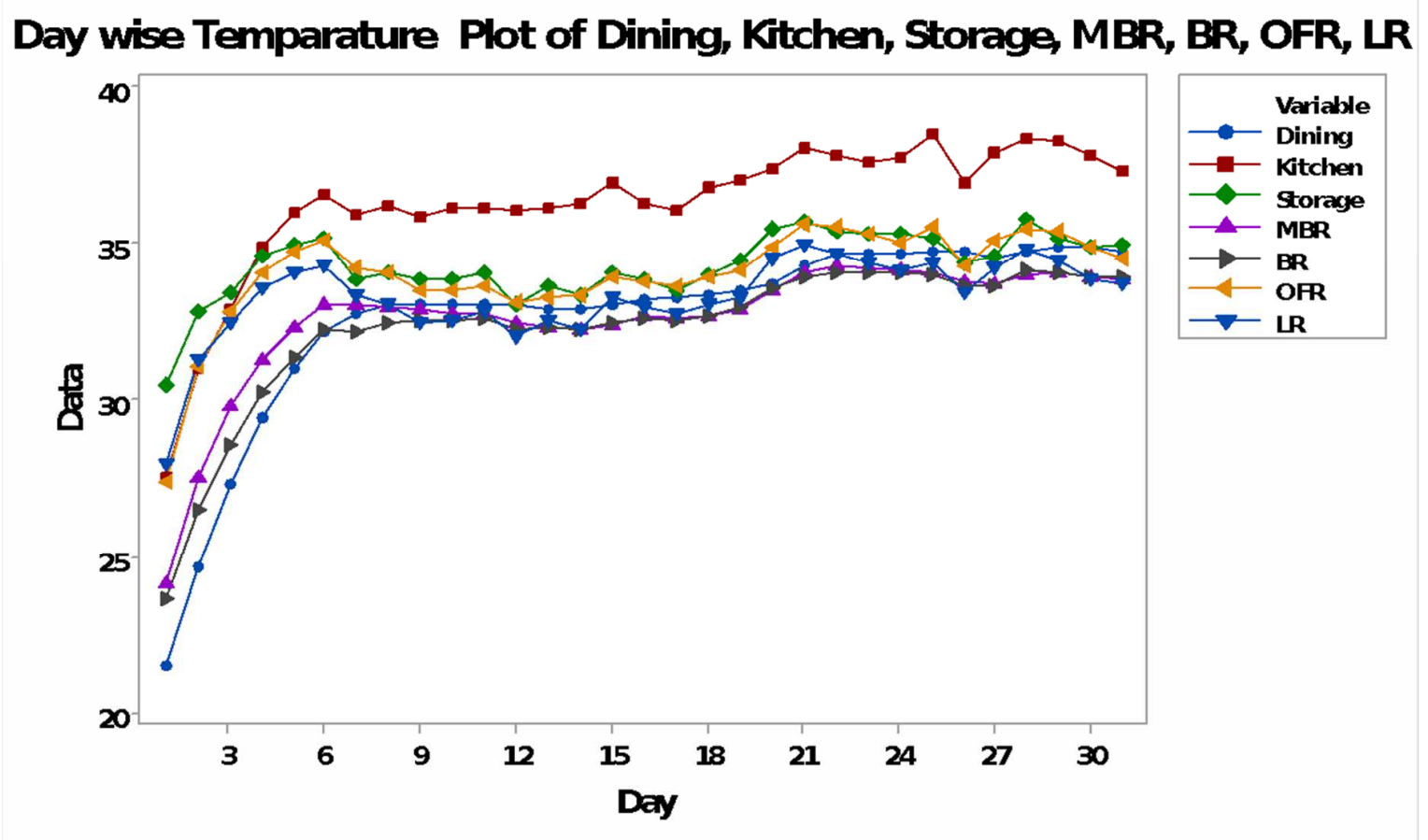

Fig. 6: Day-wise temperature plot

From the figure, it is observed that all the rooms have very high temperatures in the summer season with a peak temperature of more than $34^{\circ} \mathrm{C}$ which is higher than the ASHRAE standard comfort temperature. It also shows there is a need for a cooling system for comfort, which is realistic for Indian weather conditions. The pattern and range of temperature for all the rooms is similar. For the current research, the concern is with temperatures in the summer season as research relates to cooling load for comfortable temperatures in the summer season. There may be increased temperatures in the building zones due to internal gains, infiltration and ventilation. Hence, there is a need to modify building construction materials and operating parameters to improve building comfort levels and minimize the cooling load before designing a cooling system to maintain the standard comfort conditions inside the room. 
Building model modification: The building model modification for each zone consists of inputting regime data of the zone. The regime data includes, Zone Volume, initial values (temperature, humidity) to start simulation, infiltration (Number of air changes per hour), Ventilation(Air Change of Ventilation), Heating if the heating load is required, Cooling ( Required Room Temperature, Desired Relative humidity), Internal Gains (Heat Gain due to people, computers, lighting, other electrical appliances etc.,) Comfort type (Clothing factor, Metabolic rate, External work, Relative air velocity) and humidity capacitance ratio. Also, it is necessary to input the information regarding the wall, floor, roof and windows.

Wall Parameters namely: Wall type (Outside, Inside, Roof, Floor), Area, Category (External Internal, Adjacent, Boundary), Orientation are to be specified. Others wall parameters include solar absorptance and convective heat transfer coefficient of the wall for the front and back sides. Solar absorptance and convective heat transfer coefficient are the same for all the walls and roof surfaces.

Windows parameters namely: Window type, area, category, orientation etc are also to be specified.

Regime data, wall parameters and windows parameters of the MBR zone of the building presented below.

The building model modification parameters of the sample zone of the Master Bed Room is presented below.

Regime Data: Zone Volume: $51.51 \mathrm{~m}^{3}$; Capacitance: $61.81 \mathrm{~kJ} / \mathrm{K}$; Initial Zone temp for simulation: $27^{\circ} \mathrm{C}$; Initial Zone relative humidity for simulation:80\%; Air Change of Infiltration:0.5/h; Air Change of Ventilation:0.6/h; Desired Room temperature: $24^{\circ} \mathrm{C}$; Desired Relative Humidity: 50\%; Humidity Capacitance ratio: 1.

Internal Gains: The following internal gains are assumed for the master bedroom.

Table-4: Internal gains assumed for the master bedroom

\begin{tabular}{lcc}
\hline Item & Number & Factor \\
\hline People & 2 & 60 \\
Lights $\left(\mathrm{W} / \mathrm{m}^{2}\right)$ & 1 & 10 \\
Refrigerator(kJ/hr) & 0 & 0 \\
Computer(W) & 1 & 230 \\
Printer(W) & 1 & 50 \\
TV $(\mathrm{W})$ & 1 & 152 \\
Fans & 2 & 50 \\
\hline
\end{tabular}


Walls Data: The data on the walls of the master bedroom is presented below.

Table-5: Data on the walls of the master bedroom

\begin{tabular}{clcl}
\hline Wall No. & Wall Type & Area $\left(\mathbf{m}^{\mathbf{2}}\right)$ & \multicolumn{1}{c}{ Category } \\
\hline 1 & Outside & 12.05 & External- South \\
2 & Inside & 12.44 & Adjacent to Office Room \\
3 & Inside & 6.12 & Adjacent to Toilet 1 \\
4 & Outside & 10.42 & External west \\
5 & Floor & 15.15 & Boundary \\
6 & Roof & 15.15 & External Horizontal \\
\hline
\end{tabular}

Wall type parameters: The properties of the walls of the different categories are presented in the following tables.

Table-6: Properties of the walls of the different categories

\begin{tabular}{llccccc}
\hline Wall Type & \multicolumn{1}{c}{ Layers } & $\begin{array}{c}\text { Thickness } \\
(\mathbf{m})\end{array}$ & $\begin{array}{c}\text { conductivity/ } \\
\text { Conductance }\end{array}$ & $\begin{array}{c}\text { Density } \\
\left.\mathbf{k g} / \mathbf{m}^{\mathbf{3}}\right)\end{array}$ & $\begin{array}{c}\text { Capacity } \\
\mathbf{k J} / \mathbf{k g}-\mathbf{k})\end{array}$ & $\begin{array}{c}\mathbf{U}-\text { Value } \\
\left.\mathbf{W} / \mathbf{m}^{2}-\mathbf{K}\right)\end{array}$ \\
\hline \multirow{6}{*}{ Out Side } & & & & & \\
& Outside Film & & & & & \\
& ficient & & & & & \\
& Plaster & 0.013 & 0.721 & 1858 & 0.837 & \\
& Brick & 0.23 & 0.77 & 1922 & 0.84 & \\
& Air gap & & 5.8 & & & 1.02 \\
& Brick & 0.23 & 0.77 & 1860 & & \\
& Plaster & 0.013 & 0.721 & 1858 & 0.837 & \\
& Inside Film & & & & & \\
& ficient & & 7.69 & &
\end{tabular}

\begin{tabular}{|c|c|c|c|c|c|c|c|}
\hline Wall Type & \multicolumn{2}{|c|}{ Layers } & $\begin{array}{l}\text { Thickness } \\
\text { (m) }\end{array}$ & \multirow[t]{2}{*}{$\begin{array}{l}\text { Conductivity/ } \\
\text { Conductance }\end{array}$} & \multirow[t]{2}{*}{$\begin{array}{r}\begin{array}{r}\text { Density } \\
\left(\mathrm{kg} / \mathrm{m}^{3}\right)\end{array} \\
\end{array}$} & \multirow[t]{2}{*}{$\begin{array}{l}\text { Capacity } \\
\text { kJ/kg-k) }\end{array}$} & U-Value \\
\hline \multirow{6}{*}{ InsideWall } & Outside & Film & & & & & \\
\hline & ficient & & & 25 & & & \\
\hline & Plaster & & 0.013 & 0.721 & 1858 & 0.837 & \\
\hline & Brick & & 0.23 & 0.77 & 1922 & 0.84 & 1.98 \\
\hline & Plaster & Cilm & 0.013 & 0.721 & 1858 & 0.837 & \\
\hline & $\begin{array}{l}\text { Inside } \\
\text { ficient }\end{array}$ & Film & & 7.69 & & & \\
\hline
\end{tabular}




\begin{tabular}{|c|c|c|c|c|c|c|}
\hline $\begin{array}{l}\text { Wall } \\
\text { Type }\end{array}$ & Layers & $\begin{array}{c}\text { Thickness } \\
(\mathbf{m})\end{array}$ & $\begin{array}{l}\text { Conductivity } \\
\text { /Conductance }\end{array}$ & $\begin{array}{l}\text { Density } \\
\left.\mathbf{s g} / \mathbf{m}^{3}\right)\end{array}$ & $\begin{array}{l}\text { Capacity } \\
\mathbf{\mathbf { J }} / \mathbf{k g}-\mathbf{k})\end{array}$ & U-Value \\
\hline & $\begin{array}{l}\text { Outside Film Coefficient } \\
\text { Concrete poured in metal }\end{array}$ & & 25.00 & & & \\
\hline Roof & $\begin{array}{l}\text { Plaster } \\
\text { inside Film Coefficient }\end{array}$ & $\begin{array}{l}0.15 \\
0.01\end{array}$ & $\begin{array}{l}1.73 \\
0.72 \\
7.70\end{array}$ & $\begin{array}{l}2300.00 \\
1858.00\end{array}$ & $\begin{array}{l}1.00 \\
0.84\end{array}$ & 3.63 \\
\hline
\end{tabular}

\begin{tabular}{lllcccc}
\hline $\begin{array}{c}\text { Wall } \\
\text { Type }\end{array}$ & \multicolumn{1}{c}{ Layers } & $\begin{array}{l}\text { Thickness } \\
(\mathbf{m})\end{array}$ & $\begin{array}{c}\text { Conductivity } \\
\text { /Conductance }\end{array}$ & $\begin{array}{c}\text { Density } \\
\left(\mathbf{k g} / \mathbf{m}^{\mathbf{3}}\right)\end{array}$ & $\begin{array}{c}\text { Capacity } \\
(\mathbf{k J} / \mathbf{k g}-\mathbf{k})\end{array}$ & U-Value \\
\hline \multirow{5}{*}{ Floor } & Outside Film & & & & & \\
& ficient & & 7.69 & & & 0.51 \\
& Stone & 0.025 & 1.44 & 881 & 1.5 & \\
& Insulation & 0.078 & 0.043 & 32 & 0.75 & \\
\hline
\end{tabular}

The screenshot of TRNSYS simulation software regarding the summary of material assigned to walls, roof and floor surfaces of the master bedroom is shown in Fig.7.

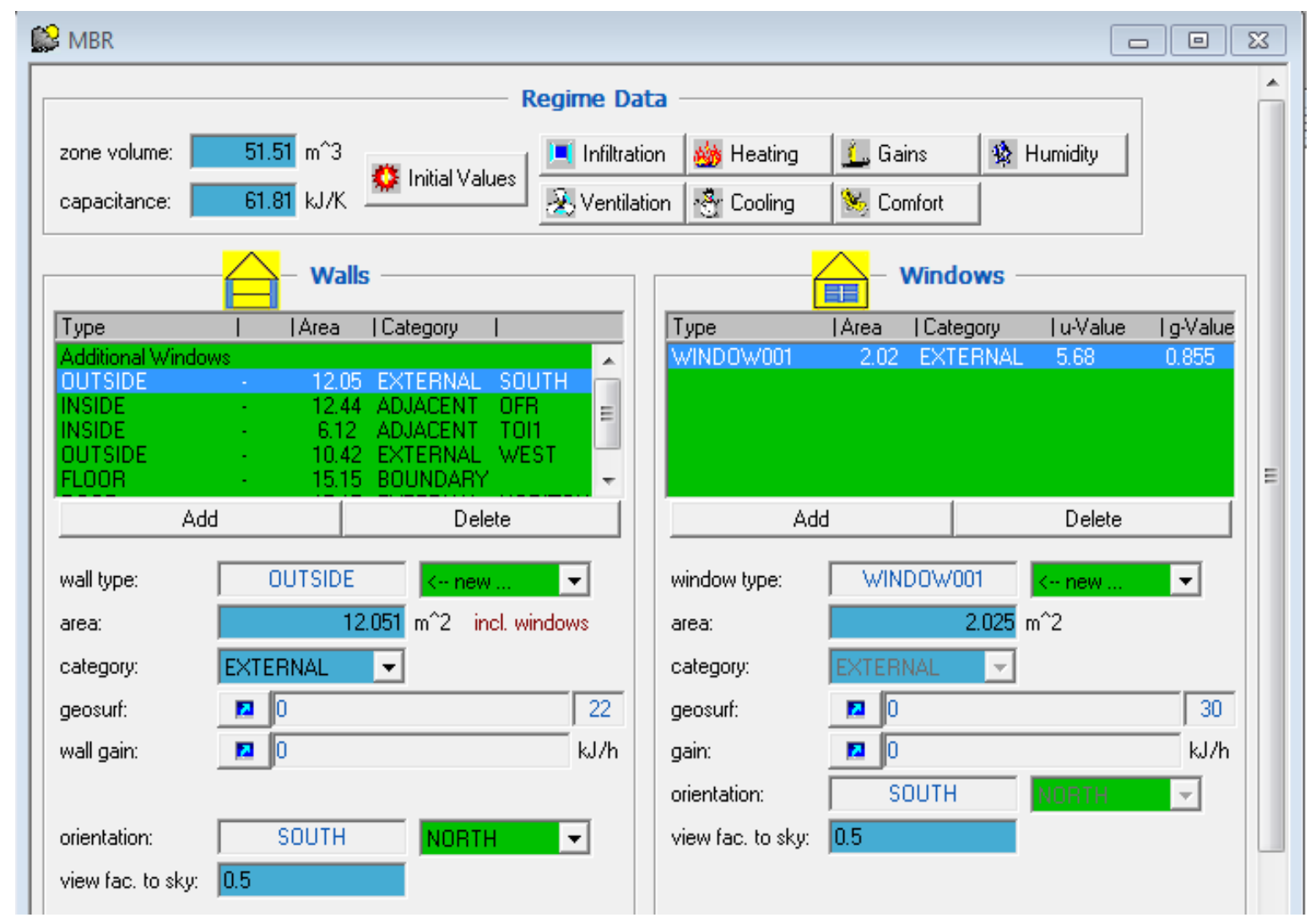

Fig. 7: Screenshot of TRNSYS simulation software 
Windows: Windows ID-1001 was selected from the ASHRAE library as an external window 1. It is a single glazed window, which is the most commonly used window type in Pakistan (author's own observation). All the properties were according to the ASHRAE standard and selected window properties and other parameters are shown with details in the following figure of the screenshot.

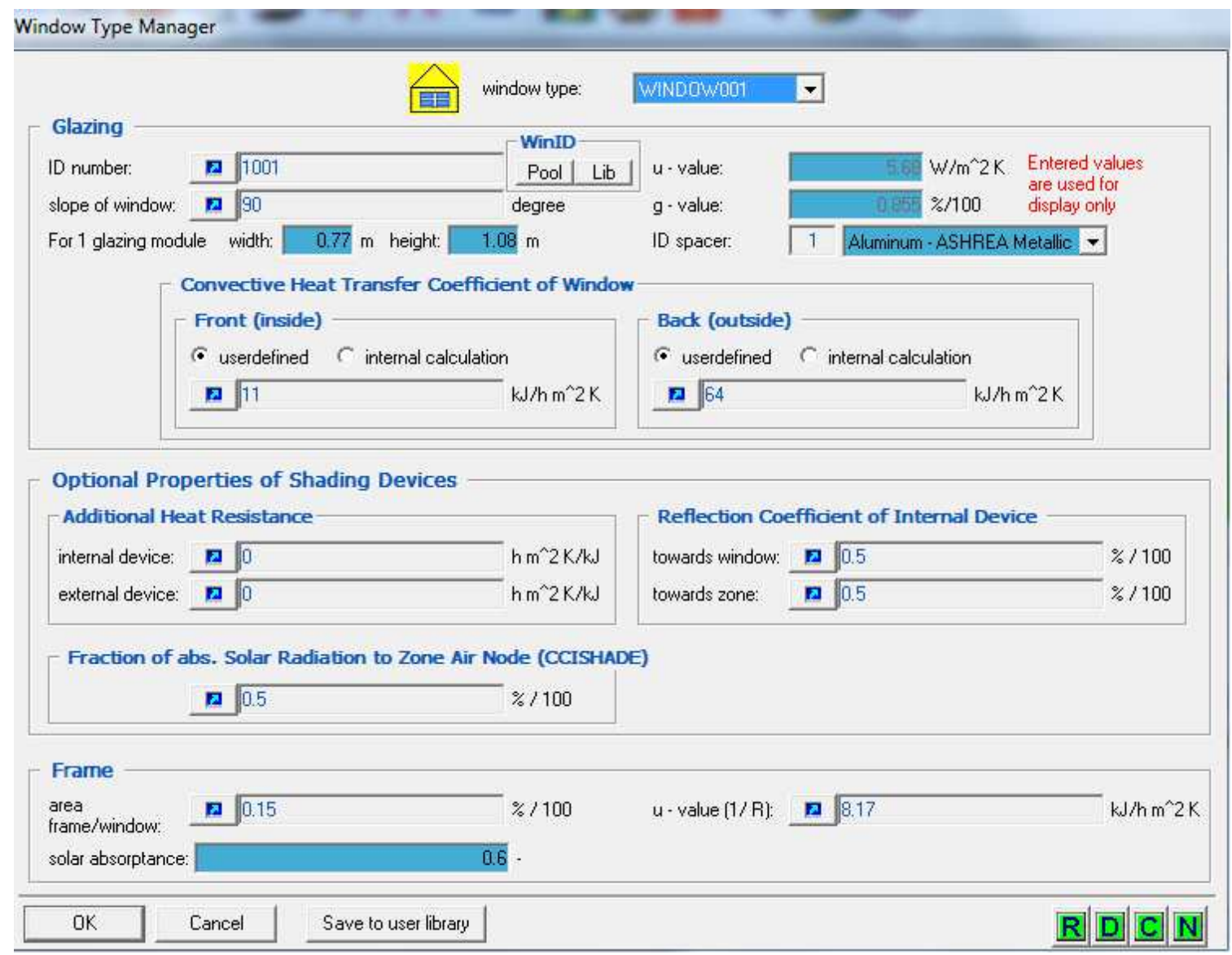

Fig. 8: All the properties according to the ASHRAE standard

Output data: For output data, it is necessary to select the thermal zones and N-type for Zone/Group of zones/surface outputs and balances. In this study, Output data like Air temperature, Sensible energy demand of the zone, total convection to air from all surfaces, Sensible infiltration energy, sensible ventilation energy, sensible coupling energy, internal convective gain, change in internal energy Latent Energy and Balances data (NTYPE 904) for each zone are considered. In the output manager, NTYPE 904 was selected. This output manager prints out the infiltration gains, ventilation gains, coupling gains, heat transmission into the wall, internal gains, wall gains and solar gains for every hour. Latent heat gain is also obtained by selecting latent energy gain from the output manager. 


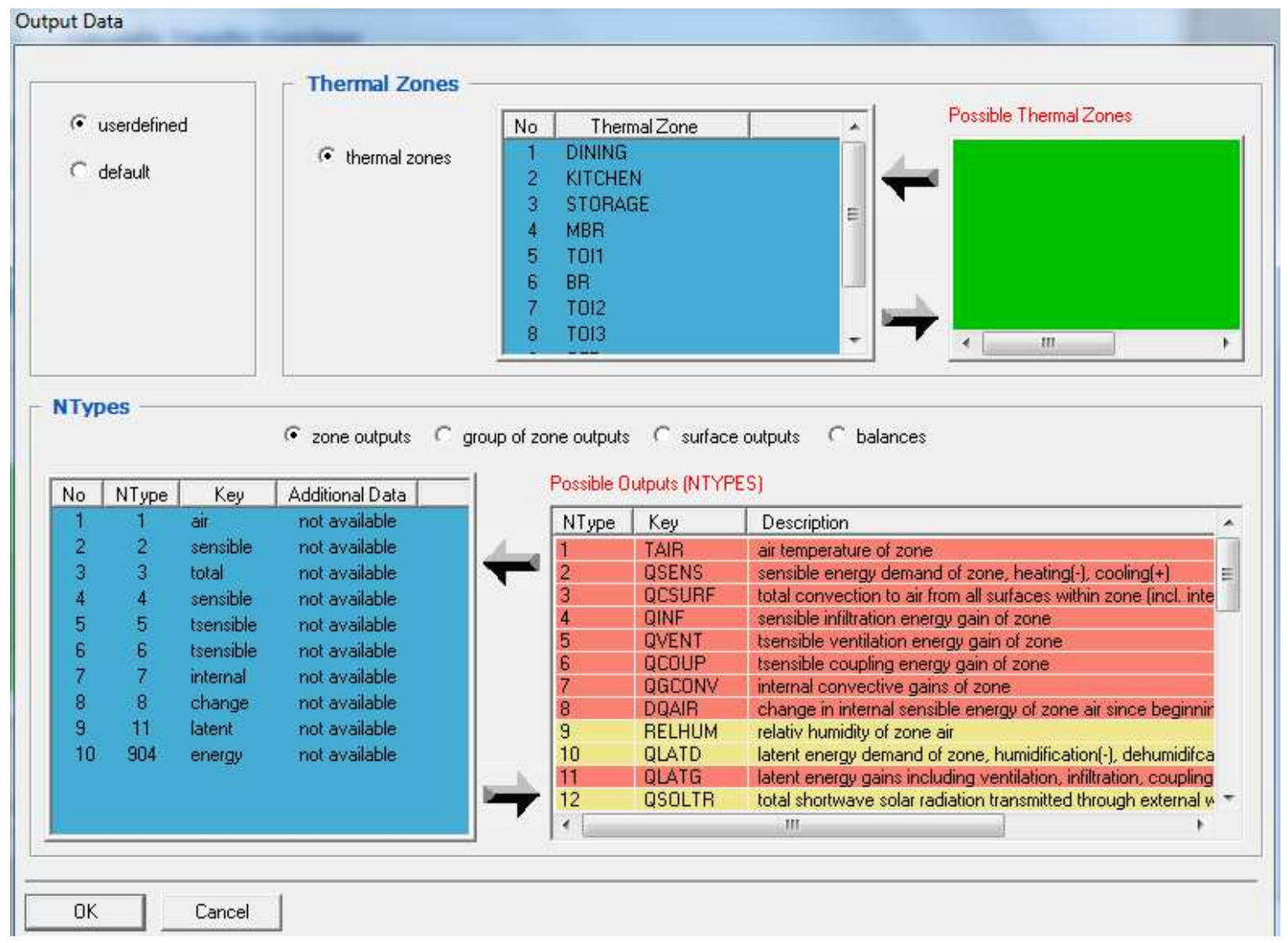

Fig. 9: Output data

Simulation results: Similarly, after assigning materials to walls, roof, floor and windows for all the zones and selecting the outputs, simulation is started for the month of May. For simulation, the following simulation parameters are specified.

Simulation Start Time: $2881 \mathrm{hr}$ (Starting of Month of May)

Simulation Stop Time: 3624 hr (End of Month of May)

The Simulation results of various heat gains for the month of May in respect of Master bedroom is presented below. 


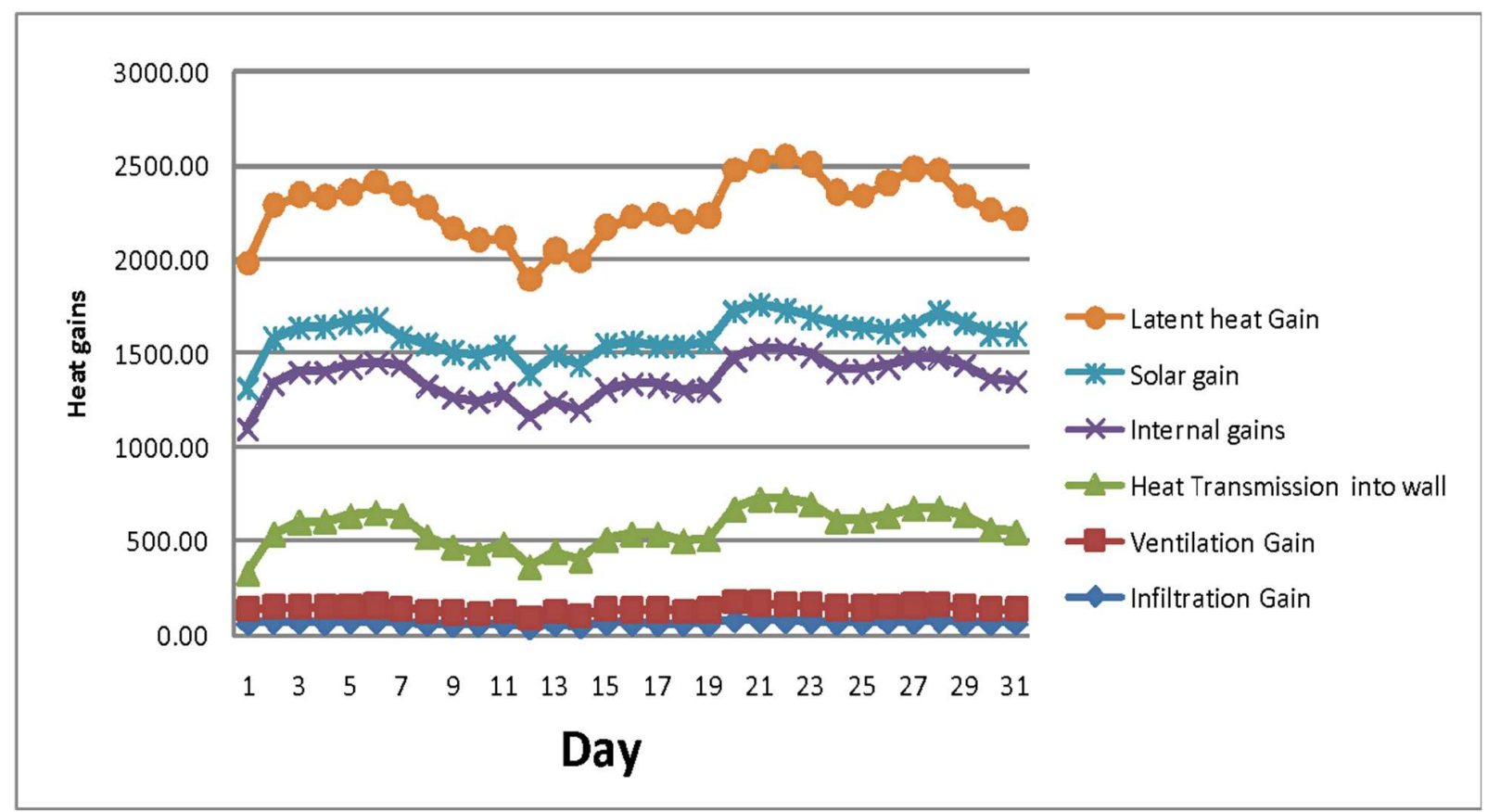

Fig. 10: Simulation results of various heat gains for the month of May of Master bedroom

Similarly, the simulation results of the other thermal zones will be obtained.

The hourly simulation Values of sensible heat gains are aggregated and converted to watts. The sensible heat gains are presented in the Table-7.

Table-7: Sensible heat gains

\begin{tabular}{|c|c|c|c|c|c|c|}
\hline Heat Gains & $\begin{array}{r}\text { Infiltrationn } \\
\text { Gain }(\mathbf{k J} / \mathbf{h}) \\
\end{array}$ & $\begin{array}{r}\text { Ventilation } \\
\text { Gain }(\mathbf{k J} / \mathbf{h}) \\
\end{array}$ & $\begin{array}{r}\text { Coupling } \\
\text { Gain }(k J / h) \\
\end{array}$ & $\begin{array}{r}\text { Heat Transmission } \\
\text { into wall }(\mathrm{kJ} / \mathrm{h})\end{array}$ & $\begin{array}{r}\text { Internal } \\
\text { gains }(\mathrm{kJ} / \mathrm{h})\end{array}$ & $\begin{array}{r}\text { Solar } \\
\text { gain }(\mathbf{k J / h})\end{array}$ \\
\hline SUM & $1.67 \mathrm{E}+05$ & $2.00 \mathrm{E}+05$ & $0.00 \mathrm{E}+00$ & $1.13 \mathrm{E}+06$ & $2.15 \mathrm{E}+06$ & $6.08 \mathrm{E}+05$ \\
\hline $\mathrm{kWH}=\operatorname{sum} / 3600$ & $4.63 \mathrm{E}+01$ & $5.55 \mathrm{E}+01$ & $0.00 \mathrm{E}+00$ & $3.15 \mathrm{E}+02$ & $5.97 \mathrm{E}+02$ & $1.69 \mathrm{E}+02$ \\
\hline kW=kWH/744 & $6.22 \mathrm{E}-02$ & 7.47E-02 & $0.00 \mathrm{E}+00$ & $4.23 \mathrm{E}-01$ & $8.02 \mathrm{E}-01$ & $2.27 \mathrm{E}-01$ \\
\hline $\mathrm{W}=\mathrm{kW} * 1000$ & 62.22 & 74.65 & 0.00 & 423.38 & 802.25 & 226.92 \\
\hline
\end{tabular}

The total sensible heat gains of the master bedroom are determined.

The Total sensible heat gain=Infiltration Gain + Ventilation gain+ Coupling gain+ Transmission gain+ Internal gain +solar gain

$$
=62.22+74.5+0.00+423.38+802.25+226.92=1589.42 \mathrm{~W}
$$

The hourly simulation Values of latent heat gains are aggregated and converted to watts. The latent heat gain of the master bedroom is arrived as $685.95 \mathrm{~W}$.

The total Cooling Load of the Master Bedroom =Sensible heat gain + Latent heat gain 


$$
=1589.42 \mathrm{~W}+685.95 \mathrm{~W}=2275.37 \mathrm{~W} .
$$

Similar calculations are made for other rooms and the cooling loads of the respective zones are presented below.

Table-8: Cooling loads of the respective zones

\begin{tabular}{|l|c|c|c|c|c|c|c|c|}
\hline \multirow{2}{*}{$\begin{array}{c}\text { Thermal } \\
\text { zone }\end{array}$} & \multicolumn{5}{|c|}{ Sensible heat gain (W) } & $\begin{array}{l}\text { Latent heat } \\
\text { gain }\end{array}$ & $\begin{array}{c}\text { Cooling } \\
\text { load }\end{array}$ & TR \\
\cline { 2 - 9 } & $\begin{array}{l}\text { Infiltration } \\
\text { gain }\end{array}$ & $\begin{array}{l}\text { Ventilation } \\
\text { gain }\end{array}$ & $\begin{array}{l}\text { HeatTransmission } \\
\text { into wall }\end{array}$ & $\begin{array}{c}\text { Internal } \\
\text { gains }\end{array}$ & Solar gain & & & \\
\hline $\begin{array}{l}\text { Master } \\
\text { Bedroom }\end{array}$ & 62.22 & 74.65 & 423.38 & 802.25 & 226.92 & 685.95 & 2275.37 & 0.6501 \\
\hline Bedroom & 58.19 & 69.82 & 560.14 & 732.07 & 19.95 & 646.58 & 2086.75 & 0.5962 \\
\hline Office Room & 33.39 & 40.06 & 580.28 & 1388.69 & 234.82 & 525.76 & 2803 & 0.8009 \\
\hline Living Room & 81.74 & 98.08 & 812.39 & 1354.57 & 416.33 & 956.08 & 3719.19 & 1.0626 \\
\hline Kitchen Room & 32.62 & 39.14 & 199.7 & 2565.44 & 178.51 & 397.84 & 3413.25 & 0.9752 \\
\hline Dining Room & 35.52 & 42.62 & 186.38 & 988.11 & 2.76 & 546.54 & 1801.93 & 0.5148 \\
\hline Work Area & 49.8 & 59.75 & 410.27 & 1010.86 & 131.75 & 564.93 & 2227.36 & 0.6364 \\
\hline Toilet 1 & 10.7 & 12.84 & 360.83 & 12.94 & 27.28 & 103.8 & 528.39 & 0.1510 \\
\hline Toilet 2 & 10.09 & 12.1 & 118.71 & 32.18 & 27.16 & 92.97 & 293.21 & 0.0838 \\
\hline Toilet 3 & 11.76 & 14.11 & 133.13 & 34.2 & 27.2 & 114.11 & 334.51 & 0.0956 \\
\hline
\end{tabular}

Heat transmission through all the surfaces $(812.39 \mathrm{~W})$, solar gain $(416.33 \mathrm{~W})$ and latent gain $(956.08 \mathrm{~W})$ is obtained with the Living room. But high internal gains $(2565.44 \mathrm{~W})$ are obtained with kitchen room. From the Table-8 it was calculated that the total cooling load is $19482.96 \mathrm{~W}$ (5.57 TR).

Distribution of the heat gains of the building is presented in Fig.11.

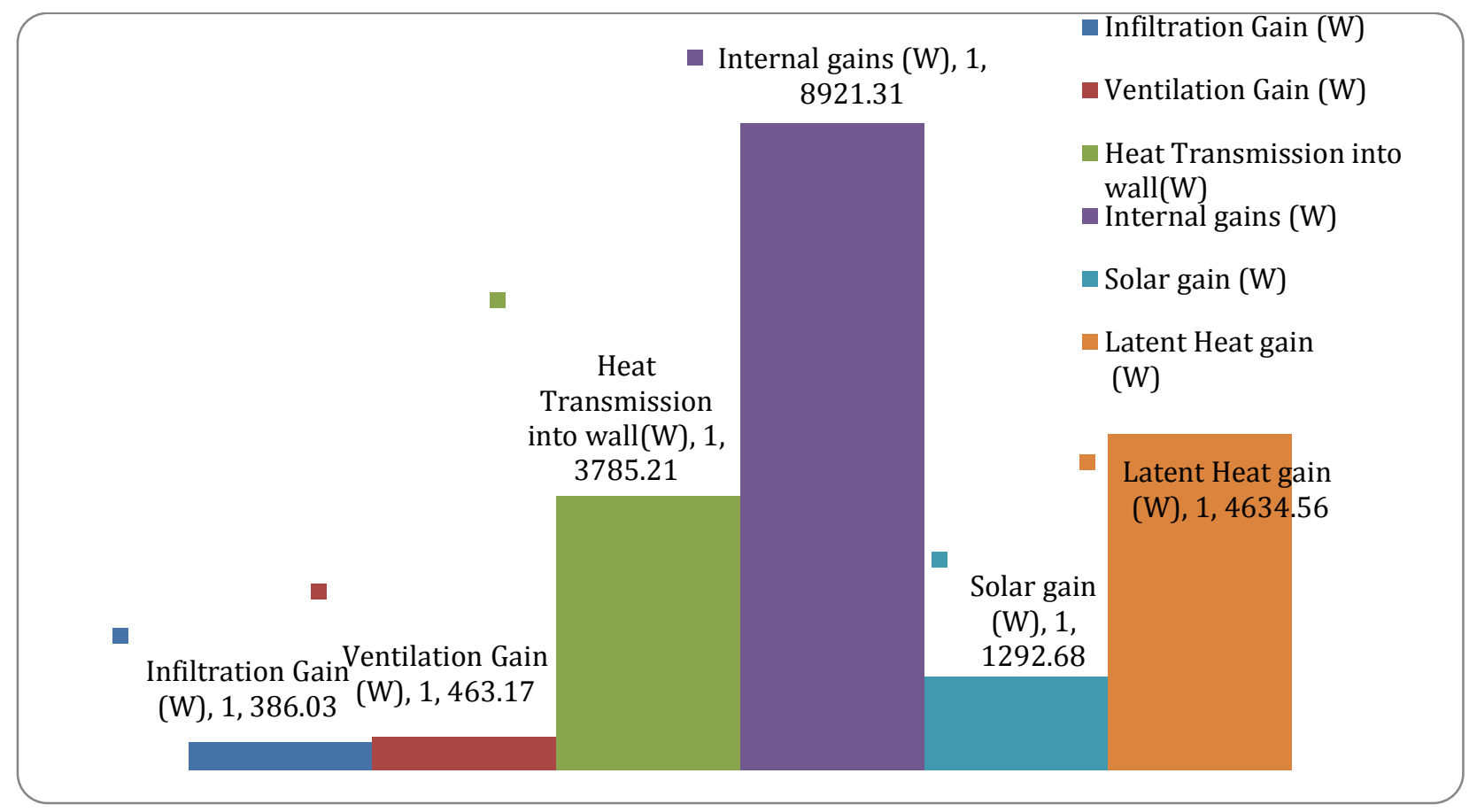

Fig. 11: Distribution of the heat gains 
From the figure, it is observed that the highest heat gains are internal gains $(8921.31 \mathrm{~W})$ and lowest heat gain $(386.03 \mathrm{~W})$ is due to infiltration.

Employing a simulation software able to evaluate the annual energy demand of a building can be are liable and effective method. In this work simulation for cooling, load determination has been performed by using TRNSYS software. TRNSYS applies the transfer functions relationships and it is able to provide the energy demands for each hour during the day. TRNSYS is based on complete weather-data containing hourly variation of temperature, solar radiation, wind velocity and relative humidity. Consequently, the annual energy demand will be calculated as a sum of hourly load values.

\section{CONCLUSIONS}

The present study reported that use of TRNSYS software for estimating building cooling load is simpler to use and is more versatile compared to any other commercially available, exorbitantly costly and extensively used software. The effects of significant building parameters like orientation, window glass shade type, number of glass panes used, wall insulation, roof type and floor type can be easily investigated. From table, it is observed that maximum infiltration gain $(81.74 \mathrm{~W})$, ventilation gain $(98.08 \mathrm{~W})$, The study will be useful for any building block to arrive at an intelligent decision regarding selection of Air conditioning requirement. This study is important to better understand the necessity of using more complex tools to evaluate and to assess the buildings energy efficiency and, consequently, a step towards a method of investigation which allows a better buildingplant coupling. The building's geometries and materials thermal properties may be changed to evaluate optimum cooling loads for a building using the TRNSYS simulation software. It is also capable of being used as a good tool to make thorough investigations of different building parameters and its orientation before starting the construction to reduce the cooling loads.

The study may be extended to find the effect of various parameters like Infiltration rate, building orientation, wall types, and windows types to find the solution to minimize the cooling loads.

\section{REFERENCES}

1. B.L.Gupta, Naveen Jha, Dhawal Vyas and Amit Daiya (2017), Performance Analysis of Solar Thermal Cooling System for an Office Building in Indian Climates using Flat Plate Collector, International Journal of Engineering and Techniques, Vol. 3, No. 4, pp. 36-40.

2. Carlos Naranjo-Mendoza and D.R. Rousse (2013), Modeling of a solar absorption cooling system for Guayaquil, Ecuador, DOI: 10.1109/ICRERA. 2013. 6749870. 
3. Carolina Aparicio-Fernández, José-Luis Vivancos, Paula Cosar-Jorda and Richard A. Buswell (2019),Energy Modelling and Calibration of Building Simulations: A Case Study of a Domestic Building with Natural Ventilation, Energies, Vol. 12, No. 3360, pp. 1-13.

4. Cristina Baglivo, Paolo Maria Congedo ID, Matteo Di Cataldo, Luigi Damiano Coluccia and Delia D’Agostino (2017), Envelope Design Optimization by Thermal Modelling of a Building in a Warm Climate, Energies, Vol. 10, No. 1808, pp. 1-34.

5. Farraj F. Al-ajmia1, Mohammad T.A. Alkhamisa, Hana M. Alsaeida (2017), Parametric simulation for energy-efficient building design of Kuwaiti domestic buildings, Journal of Buildings and Sustainability, Vol. 01, No. 01, pp. 48-60.

6. Franck Lucas, Thierry A. Mara, François Garde, Harry Boyer (1998), A Comparison between CODYRUN and TRNSYS, simulation models for thermal buildings behaviour, Word Renewable Energy Congress, Sep 1998, Florence, Italy, pp. 1-10.

7. Hani H. Sait (2013), Estimated Thermal Load and Selecting of Suitable Air-Conditioning Systems for a Three Story Educational Building, The $3^{\text {rd }}$ International Conference on Sustainable Energy Information Technology (SEIT 2013), Procedia Computer Science, Vol. 19, pp. 636-645.

8. Le, Khoa Xuan; Huang, Ming Jun; and Hewitt, Neil J. (2018), Domestic High-Temperature Air Source Heat Pump: Performance Analysis Using TRNSYS Simulations, $5^{\text {th }}$ International High-Performance Buildings Conference at Purdue, July 9-12, 2018, No. 3636, pp. 1-10.

9. Luca Evangelisti, Gabriele Battista, Claudia Guattari, Carmine Basilicata and Roberto de LietoVollaro (2014), Analysis of Two Models for Evaluating the Energy Performance ofDifferent Buildings, Sustainability, Vol. 2014, No. 6, pp. 5311-5321.

10. Matteo Dongellinia, MassimilianoAbbenantea and Gian Luca Morini (2016), Energy performance assessment of the heating system refurbishment on a school building in Modena, Italy, $71^{s t}$ Conference of the Italian Thermal Machines Engineering Association, ATI2016, 14-16 September 2016, Turin, Italy, Energy Procedia, No. 101, pp. 948-955.

11. Nilufer Egrican and Alpay Akguc (2011), Thermal Performance Estimation of the Office Building with the Building Integrated Photovoltaic System, Proceedings of the ASME 2011 5th International Conference on Energy Sustainability, August 7-10, 2011, Washington, DC, USA, pp.1-11.

12. Petrus Tri Bhaskoro and Syed Ihstham UI HaqGilani (2011), Transient Cooling Load Characteristics of an Academic Building, using TRNSYS, Journal of Applied Sciences, Vol. 11, No.10, pp.17771783. 
13. Wenting Ma, Moon Keun Kim and JianliHao (2019), Numerical Simulation Modeling of a GSHP and WSHP System for an O_ce Building in the Hot Summer and Cold Winter Region of China: A Case Study in Suzhou, Sustainability 2019, Vol.11, No.3282, pp.1-17.

14. Y. Takahashi, G. Yoon, M. Yoshinaga, and R. Chiba (2014), Comparative Study On Simulation Tools Of Annual Heat Load For Energy Management, A SIMU 2014-IBPSA Asia Conference, Nagoya, Japan, November 28-29.

15. YamiléDíaz-Torres, Yarelis Valdivia-Noda, José Pedro Monteagudo-Yanes and Yudit MirandaTorres (2017). Application of building energy simulation in the validating of operational strategies of HVAC systems on a tropical hotel, IngenieríaMecánica, Vol. 20, No. 1, pp. 31-38. 